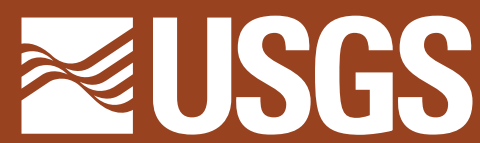

science for a changing world

Prepared in cooperation with the South Florida Water Management District

\title{
An Overview of Urban Stormwater-Management Practices in Miami-Dade County, Florida
}

Open-File Report 2004-1346

U.S. Department of the Interior

U.S. Geological Survey 